\title{
Determination of an efficient and reliable method for DNA extraction from ticks
}

\author{
Lénaïg HALOS ${ }^{\mathrm{a}}$, Taoufik JAMAL ${ }^{\mathrm{a}}$, Laurence VIAL ${ }^{\mathrm{b}}$, Renaud MAILLARD ${ }^{\mathrm{a}, \mathrm{c}}$, \\ Antonia SUAU ${ }^{\mathrm{d}}$, Arnaud LE MENACH ${ }^{\mathrm{e}}$, Henri-Jean BOULOUIS ${ }^{\mathrm{a}}$, \\ Muriel VAYSSIER-TAUSSAT ${ }^{\mathrm{a} *}$ \\ a UMR 956 INRA/AFSSA/ENVA/UVPM, Microbiologie, École Nationale Vétérinaire, \\ 7 avenue du Général de Gaulle, 94703 Maisons-Alfort, France \\ b IRD Montpellier, CEPM, 911 avenue Agropolis, 34090 Montpellier, France \\ ${ }^{\mathrm{c}}$ Unité de pathologie du bétail, École Nationale Vétérinaire, 7 rue du Général de Gaulle, \\ 94703 Maisons-Alfort, France \\ ${ }^{d}$ Laboratoire de Biotechnologies, Centre National des Arts et Métiers, 2 rue Conté, 75003 Paris, France \\ e INSERM U444, Hôpital Saint-Antoine, 27 rue Chaligny, 75571 Paris Cedex 12, France
}

(Received 27 January 2004; accepted 19 May 2004)

\begin{abstract}
Molecular detection of pathogenic microorganisms in ticks is based on DNA amplification of the target pathogen; therefore, extraction of DNA from the tick is a major step. In this study, we compared three different tick DNA extraction protocols based on an enzymatic digestion by proteinase $\mathrm{K}$ followed by DNA extraction by a commercial kit (method 1), or on mortar crushing, proteinase $\mathrm{K}$ digestion and phenol/chloroform DNA extraction (method 2) and fine crushing with a beads beater, proteinase K digestion and DNA extraction using a commercial kit (method 3). The absence of PCR inhibitors and the DNA quality were evaluated by PCR amplification of the tick mitochondrial 16S rRNA gene using tick-specific primers. With method 1 , 23/30 (77\%) of the samples were extracted; with method 2, 30/31 (97\%) of the samples were extracted and with method 3,30/30 (100\%) of the samples were extracted. DNA extraction efficiency using method 3 is significantly higher than DNA extraction efficiency using method 1 $(100 \%$ versus $77 \%, P<0.05)$. There was no significant difference between methods 2 and 3 . Method 3 was however more adapted to cohort studies than method 2. This technique was validated for cohort tick DNA extraction and applicable to the treatment of small samples such as nymphs and soft ticks with $100 \%$ efficiency.
\end{abstract}

tick / DNA extraction / PCR / nymphal stage

\section{INTRODUCTION}

Ticks (Acari: Ixodida) are ubiquitous ectoparasitic arthropods and vectors of many pathogen microorganisms such as Babesia sp., Borrelia sp., Rickettsia sp., and Ehrlichia sp., all of which pose a significant medical threat to humans and animals $[8,11]$. Ticks are implicated in the transmission of numerous zoonoses since the same tick can feed on different kinds of hosts at the different stages of its life cycle. Molecular detection of pathogens in ticks is based on the PCR amplification of DNA from the targeted

* Corresponding author: mvayssier@vet-alfort.fr 
microorganism, however, tick DNA extraction is often problematic [7, 9]. Firstly, ticks possess a hard chitinous exoskeleton that must be disrupted before extraction, secondly, for unknown reasons, DNA extracted from ticks appears to be highly susceptible to degradation $[5,6]$ and finally, the possible presence of Taq-polymerase inhibitors has also been implicated in both engorged and unfed ticks $[6,9,11]$. These factors may play a role in decreasing the efficiency of PCR amplification. For example, polysaccharides co-purified with DNA have been shown to limit the use of the extracted DNA [5]. These limitations could also have an impact on tick infection rates reported in previous studies. There is, therefore, an obvious need for standardized DNA extraction methods, enabling the preparation of DNA from large cohorts of ticks and the comparison of results from one study to another.

In this study, we compared three DNA extraction protocols based on differences in the disruption of the exoskeleton and extraction of DNA from adult ticks belonging to the three more represented ticks in Europe, i.e., Dermacentor sp., Rhipicephalus sp. and Ixodes ricinus. We then proposed the use of one easy, rapid, efficient and reliable DNA extraction method based on mechanical disruption of the exoskeleton followed by the enzymatic degradation of proteins before DNA extraction using a commercial kit. We applied this technique to samples of small size, i.e., nymphs as well as to soft ticks (Alectorobius sonrai) and showed 100\% efficiency whatever the stage and the genera of the ticks.

\section{MATERIALS AND METHODS}

\subsection{Tick samples}

In order to determine the most efficient and reliable method for DNA extraction from ticks, we used homogenized samples composed of 29 adults ( 15 unfed males and
14 engorged females) of Dermacentor $\mathrm{sp}$. all collected on bovines in the Aveyron department in France, 30 adults (15 unfed males and 15 engorged females) of Rhipicephalus sp. all collected on dogs in Tunisia, and 32 adults of Ixodes ricinus (16 unfed males, 7 collected by flagging a pasture in the Yvelines department in France, 9 collected from cats (Paris, France) and 16 engorged females all collected from cats in Paris (France)). We applied the most efficient DNA extraction method to 55 questing nymphs of Ixodes ricinus collected by flagging a pasture in Puy-de-Dôme (France) and to 32 soft ticks: Alectorobius sonrai (17 unfed males and 15 questing nymphs) all collected from a rodents burrow in Senegal. All the ticks were first identified under binocular lens and kept individually in absolute ethanol before being treated.

\subsection{Tick DNA extraction methods}

Each tick was first washed in three sterile water baths followed by one absolute ethanol bath, air dried and collected in sterile microtubes. Three methods of DNA extraction were tested.

\subsubsection{Method 1}

DNA extraction was performed using the Qiamp DNA extraction kit for tissue protocol (Qiagen, Hilden, Germany). The ticks were first roughly torn to pieces in $180 \mu \mathrm{L}$ ATL buffer (provided in the kit) and treated with proteinase $\mathrm{K}(100 \mu \mathrm{g} / \mathrm{mL})$ for $16 \mathrm{~h}$ $\left(56^{\circ} \mathrm{C}\right)$. The subsequent steps were carried out according to the manufacturer's instructions.

\subsubsection{Method 2}

The ticks were mechanically crushed using a Dounce mortar in $1 \mathrm{~mL}$ lysis buffer ( $\mathrm{NaCl} 0.1 \mathrm{M}$, Tris-HCl 0.21M, pH8 EDTA $0.05 \mathrm{M}$, SDS $0.5 \%)$. Enzymatic digestion by proteinase $\mathrm{K}(100 \mu \mathrm{g} / \mathrm{mL})$ was performed for $16 \mathrm{~h}\left(56^{\circ} \mathrm{C}\right)$. DNA extraction was then 
carried out using phenol-chloroform (1/2; $1 / 2$ ) extraction [12]. The DNA was then precipitated with absolute ethanol (two volumes) and resuspended in $200 \mu \mathrm{L}$ of $1 \times \mathrm{TE}$ buffer (Tris $10 \mathrm{mM}$, EDTA $1 \mathrm{mM}$, pH8).

\subsubsection{Method 3}

Each sample was collected in a $2 \mathrm{~mL}$ sterile microtube containing sterile microbeads (Qiagen, Germany): 10 glass microbeads ( $1 \mathrm{~mm}$ diameter) and 1 steel micro-bead (4 $\mathrm{mm}$ diameter). The tubes were cooled in liquid nitrogen for $1 \mathrm{~min}$ and crushed by shaking with a bead beater (mixer mill MM301, Qiagen) for 2 cycles of $1 \mathrm{~min} 30 \mathrm{~s}$ at a frequency of 25 . The tubes were then briefly centrifuged at a maximum speed $(10000 \mathrm{~g})$ and the samples were suspended in $180 \mu \mathrm{L}$ of lysis buffer (ATL buffer, Qiagen). DNA was then extracted using the Qiamp DNA extraction kit for tissue protocol (Qiagen).

The final elution volume was $200 \mu \mathrm{L}$ for each extraction method.

\subsection{Polymerase chain reaction}

The efficiency of tick DNA extraction was evaluated by amplification of the tick mitochondrial 16S rRNA gene (ribosomal DNA [rDNA]) using-tick specific primers: TQ16S+1F 5'CTG CTC AAT GAT TTT TTA AAT TGC TGT GG 3' and TQ16S2R 5' ACG CTG TTA TCC CTA GAG 3' [2]. Each reaction was carried out in $50 \mu \mathrm{L}$ volume containing $0.5 \mu \mathrm{mol} / \mu \mathrm{L}$ of each oli- gonucleotide primer, $2.5 \mathrm{mM}$ of each dNTP, $5 \mu \mathrm{L}$ of $10 \times$ PCR buffer, $1 \mathrm{U}$ of Taq DNA polymerase (TaKaRa biomedical group, Shiga, Japan) and $5 \mu \mathrm{L}$ of the DNA extract and was made up to $50 \mu \mathrm{L}$ with sterile water. PCR was performed in a GenAmp thermocycler (Applied biosystem, Courtabœuf, France) with 1 cycle of denaturation ( $8 \mathrm{~min}$, $\left.94^{\circ} \mathrm{C}\right)$, followed by 10 cycles of denaturation $\left(1 \mathrm{~min}, 92^{\circ} \mathrm{C}\right)$ annealing $\left(1 \mathrm{~min}, 48^{\circ} \mathrm{C}\right)$ and extension $\left(1 \min 30 \mathrm{~s}, 72{ }^{\circ} \mathrm{C}\right)$ then 32 cycles of denaturation $\left(1 \min 92{ }^{\circ} \mathrm{C}\right)$, annealing $\left(1 \mathrm{~min}, 54^{\circ} \mathrm{C}\right)$, extension $(1 \mathrm{~min}$ $30 \mathrm{~s}, 72{ }^{\circ} \mathrm{C}$ ) and a final extension step (10 min, $72^{\circ} \mathrm{C}$ ) as described previously [2].

DNA electrophoresis was carried out in $2 \%$ agarose gels containing ethidium bromide, and DNA fragments were visualized under ultraviolet light.

\subsection{Statistical analysis}

Chi-square for trends and the Fisher exact test for dichotomous variables were performed on SAS/Stat ${ }^{\circledR}$ (V.8.02) software. $P<0.05$ was regarded as significant.

\section{RESULTS}

With method 1, 23/30 (77\%) of the extracted samples, 30/31 (97\%) of the samples extracted with method 2 and 30/30 (100\%) of the samples extracted with method 3 were successfully amplified using the tick specific primers (Tab. I). Method 3 efficiency

Table I. Efficiency of three different DNA extraction methods on adult tick samples. The evaluation of the extraction efficiency was performed by specific amplification of $16 \mathrm{~S}$ rDNA of tick origin.

\begin{tabular}{|c|c|c|c|c|}
\hline \multirow[t]{2}{*}{ Extraction method efficiency } & \multicolumn{4}{|c|}{$\begin{array}{l}\text { Number of amplified samples from adult } \\
\text { tick DNA/number of samples }(\%)\end{array}$} \\
\hline & Dermacentor & Rhipicephalus & Ixodes ricinus & Total \\
\hline Method 1: proteinase $\mathrm{K}$ and Qiagen kit & $8 / 10(80)$ & $7 / 10(70)$ & $8 / 10(80)$ & $23 / 30(77)$ \\
\hline $\begin{array}{l}\text { Method 2: mortar crushing, } \\
\text { proteinase } \mathrm{K} \text { and phenol-chloroform }\end{array}$ & 8/9 (89) & $11 / 11(100)$ & 11/11 (100) & $30 / 31(97)$ \\
\hline $\begin{array}{l}\text { Method 3: beads beater, proteinase } \mathrm{K} \\
\text { and Qiagen kit }\end{array}$ & $9 / 9(100)$ & $10 / 10(100)$ & $11 / 11(100)$ & $30 / 30(100)$ \\
\hline
\end{tabular}


was statistically different from method 2 efficiency $(100 \%$ versus $77 \%, P<0.05)$ while no significant difference, in terms of efficiency, was found between methods 2 and 3. Whatever the method we used, no difference in DNA extraction was observed according to the tick genera, i.e., Dermacentor sp., Rhipicephalus sp., Ixodes ricinus, or the engorged status (data not shown).

Method 3 was then used to extract DNA from Ixodes ricinus nymphs and from soft ticks (Alectorobius sonrai). DNA extraction was confirmed as described by specific amplification of the $16 \mathrm{~S}$ mitochondrial gene. For all of the 55 (100\%) nymphal Ixodes ricinus samples, a 320-bp fragment of the $16 \mathrm{~S}$ mitochondrial gene was amplified using tick-specific primers. In addition, the specific amplification of the same fragment for all of the 32 samples (100\%) of Alectorobius sonrai, (15 nymphs, 17 adults) also confirmed the efficiency of the method.

\section{DISCUSSION}

We describe a DNA extraction method that combined the mechanical and disruptive properties of the bead beater with protein digestion and the use of a commercial kit, which enabled DNA extraction with $100 \%$ efficiency from ticks.

Compared to method 2 and to other efficient methods already described [5, 6], method 3 is particularly well adapted to cohort studies and for samples of small size such as nymphs but also larvae (data not shown). Interestingly, no difference in DNA extraction efficiency was detected with different engorgement statuses of the ticks.

The amplification of a fragment of the tick mitochondrial 16S rRNA gene is a necessary positive control to confirm the efficiency of DNA extraction $[6,11]$. This is an important step for studies where the detection of DNA of pathogens is carried out using PCR amplification. This confirms the quality of the DNA being amplified, as well as the absence of potentially inhibitory factors. The extreme variability of tick infec- tion rates that have been reported by previous studies emphasizes the need for such a positive control. For example, studies in which extraction controls were not always performed and concerning the Babesia sp. infection rates of ticks give results between $6.2 \%$ and $62 \%$ of infection in questing [1, $3,10]$ or engorged ticks [4]. Since an internal control was not systematically used, the impact on the infection rates accorded to environmental conditions could be biased by the extraction results.

We show that enzymatic protein degradation before DNA extraction is not sufficient for maximum isolation of DNA. It must be associated with an initial step of fine crushing, which is probably due to the need for mechanical destruction of the polysaccharide chains of the chitin of the tick exoskeleton [5]. The mortar crush is an efficient method for tick DNA extraction (97\% efficiency) however, it is time consuming and difficult to apply to small samples such as nymphs (results not shown). Bead beating offers the best and most reliable results (100\% efficiency) for hard and soft ticks of both the adult and nymphal stage.

After crushing and protein digestion, DNA extraction techniques with phenol/chloroform or with a commercial kit could be both used despite phenol/chloroform extraction being poorly adapted to cohort studies.

Thus, the combined "bead beater- protein digestion- kit extraction" method that we established, offers maximal efficiency in terms of rapidity, number and size samples to be treated. The use of this method combined with the use of a positive control in studies for which tick DNA extraction is required should standardize the results from different laboratories and thus enable accurate and therefore significant comparisons.

\section{ACKNOWLEDGEMENTS}

We thank Cédric Trottet and Benjamin Girard for their excellent technical assistance and Maria Mavris for critical reading of the manuscript. 


\section{REFERENCES}

[1] Battsetseg B., Lucero S., Xuan X., Claveria F.G., Inoue N., Alhassan A., Kanno T., Igarashi I., Nagasawa H., Mikami T., Fujisaki K., Detection of natural infection of Boophilus microplus with Babesia equi and Babesia caballi in Brazilian horses using nested polymerase chain reaction, Vet. Parasitol. 107 (2002) 351-357.

[2] Black W.C. 4th, Piesman J., Phylogeny of hard and soft-tick taxa (Acari: Ixodida) based on mitochondrial 16S rDNA sequences, Proc. Natl. Acad. Sci. USA 91 (1994) 10034-10038.

[3] Duh D., Petrovec M., Avsic-Zupanc T., Diversity of Babesia infecting European sheep ticks (Ixodes ricinus), J. Clin. Microbiol. 39 (2001) 3395-3397.

[4] Foppa I.M., Krause P.J., Spielman A., Goethert H., Gern L., Brand B., Telford S.R. 3rd, Entomologic and serologic evidence of zoonotic transmission of Babesia microti, eastern Switzerland, Emerg. Infect. Dis. 8 (2002) 722-726.

[5] Hill C.A., Gutierrez J.A., A method for extraction and analysis of high quality genomic DNA from ixodid ticks, Med. Vet. Entomol. 17 (2003) 224-227.

[6] Hubbard M.J., Cann K.J., Wright D.J., Validation and rapid extraction of nucleic acids from alcohol-preserved ticks, Exp. Appl. Acarol. 19 (1995) 473-478.
[7] Mauel M.J., Carlton S.J., Mather T.N., Polymerase chain reaction detection efficiency of the human granulocytic ehrlichiosis agent (Rickettsiaceae: Ehrlichieae) in ticks (Acari: Ixodidae) is dependent on the DNA extraction method, J. Med. Entomol. 36 (1999) 649-652.

[8] Parola P., Raoult D., Ticks and tickborne bacterial diseases in humans: an emerging infectious threat, Clin. Infect. Dis. 32 (2001) 897928.

[9] Schwartz I., Varde S., Nadelman R.B., Wormser G.P., Fish D., Inhibition of efficient polymerase chain reaction amplification of Borrelia burgdorferi DNA in blood-fed ticks, Am. J. Trop. Med. Hyg. 56 (1997) 339-342.

[10] Skotarczak B., Wodecka B., Cichocka A., Coexistence DNA of Borrelia burgdorferi sensu lato and Babesia microti in Ixodes ricinus ticks from north-western Poland, Ann. Agric. Environ. Med. 9 (2002) 25-28.

[11] Sparagano O.A., Allsopp M.T., Mank R.A., Rijpkema S.G., Figueroa J.V., Jongejan F., Molecular detection of pathogen DNA in ticks (Acari: Ixodidae): a review, Exp. Appl. Acarol. 23 (1999) 929-960.

[12] Wallace D.M., Large and small scale phenol extractions, in: Berger S.L., Kimmel R. (Eds.), Guide to molecular cloning techniques, Academic Press, Orlando, 1987, pp. 31-41. 